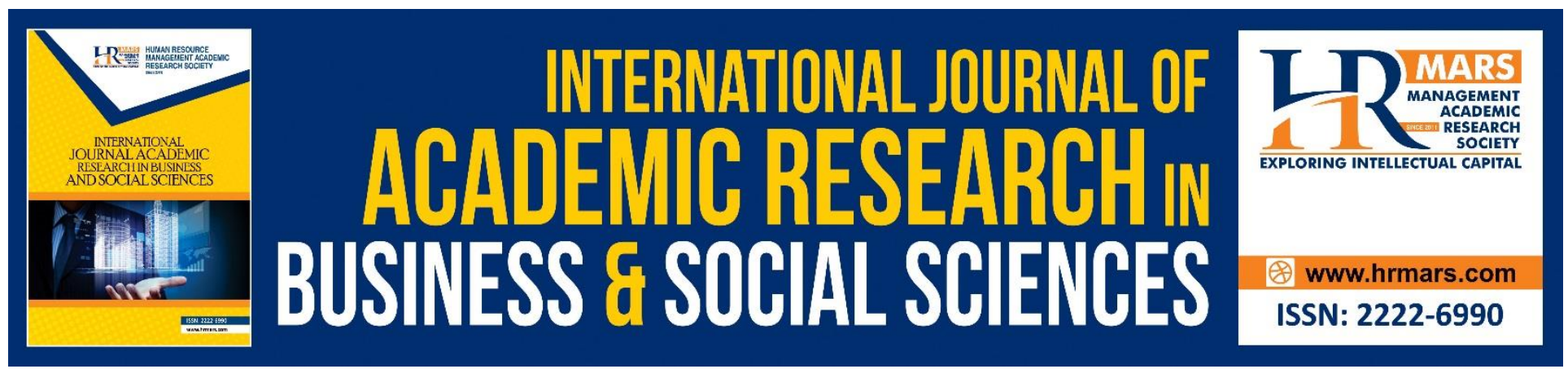

\title{
Motivations for Paying Income Zakat among UniSHAMS' Employees
}

\section{Yusuf Haji-Othman, Mohd Sholeh Sheh Yusuff \& Mohd Farid Abd Latib}

To Link this Article: http://dx.doi.org/10.6007/IJARBSS/v8-i10/4768

DOI: $10.6007 /$ IJARBSS/v8-i10/4768

Received: 22 Sept 2018, Revised: 21 Oct 2018, Accepted: 26 Oct 2018

Published Online: 31 October 2018

In-Text Citation: (Haji-Othman, Yusuff, \& Latib, 2018)

To Cite this Article: Haji-Othman, Y., Yusuff, M. S. S., \& Latib, M. F. A. (2018). Motivations for Paying Income Zakat among UniSHAMS' Employees. International Journal of Academic Research in Business and Social Sciences, 8(10), 619-628.

Copyright: (C) 2018 The Author(s)

Published by Human Resource Management Academic Research Society (www.hrmars.com)

This article is published under the Creative Commons Attribution (CC BY 4.0) license. Anyone may reproduce, distribute, translate and create derivative works of this article (for both commercial and non-commercial purposes), subject to full attribution to the original publication and authors. The full terms of this license may be seen

at: http://creativecommons.org/licences/by/4.0/legalcode

Vol. 8, No. 10, 2018, Pg. 619 - 628

http://hrmars.com/index.php/pages/detail/IJARBSS

JOURNAL HOMEPAGE

Full Terms \& Conditions of access and use can be found at http://hrmars.com/index.php/pages/detail/publication-ethics 


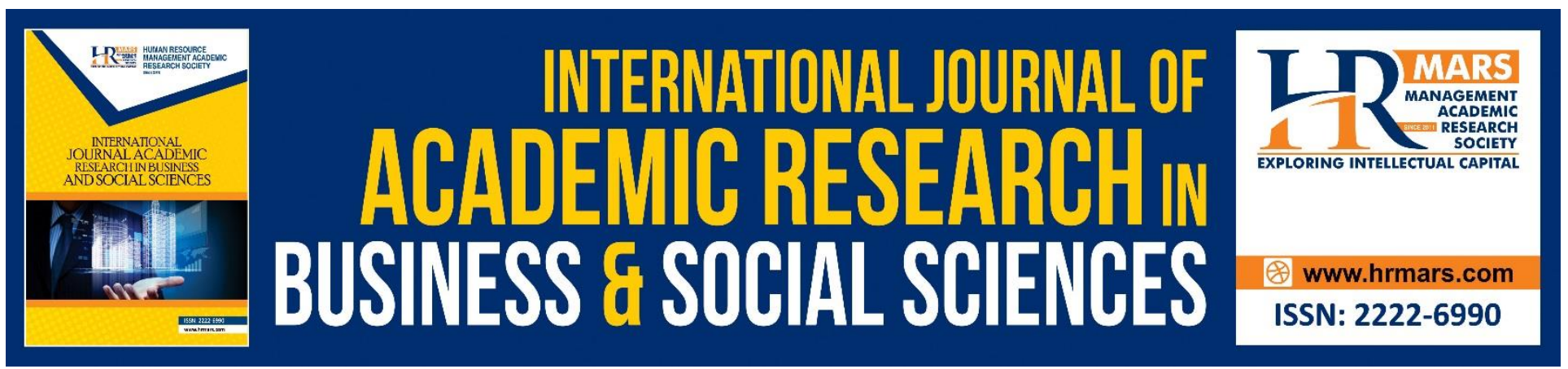

\title{
Motivations for Paying Income Zakat among UniSHAMS' Employees
}

\author{
Yusuf Haji-Othman ${ }^{1}$, Mohd Sholeh Sheh Yusuff ${ }^{2}$ \& Mohd Farid Abd \\ Latib $^{3}$ \\ ${ }^{1,3}$ Kulliyyah of Muamalat and Management Sciences, Sultan Abdul Halim Mu'adzam Shah \\ International Islamic University (UniSHAMS), 09300 Kuala Ketil, Kedah. \\ ${ }^{2}$ Kulliyyah of Usuluddin and Quranic Sciences, Sultan Abdul Halim Mu'adzam Shah International \\ Islamic University (UniSHAMS), 09300 Kuala Ketil, Kedah. \\ Email, corresponding author: dryusufhajiothman@unishams.edu.my
}

\begin{abstract}
This study examines motivations for paying income zakat among UNISHAMS employees using a qualitative approach. Using interview methods, this study finds that there is a variety of motivations for income zakat compliance. Among the common themes of motivations are religious obligation, knowledge about zakat, helping the poor, confidence in fair distribution of zakat collection to asnaf, reward from Allah, helping Muslim community, influence of parents, influence of zakat officers, tax rebate incentive, purify one's income and property, influence of spouse, influence of family, convenience to pay zakat and influence of religious teachers. This study recommends that more comprehensive studies to be done in the area of zakat compliance behavior using qualitative approach and future studies should focus on internal or psychological motivations. In addition, this study proposes that future studies regarding compliance behavior of religious obligations such as compliance behavior of zakat, Islamic banking, takaful, faraid, waqaf and others adapt and adopt the theory proposed by this study. It is hoped that compliance behavior of religious obligations would be a fertile area of research in the future.
\end{abstract}

Keywords: Motivation, Compliance, Zakat, Religiosity.

\section{Introduction}

Zakat is one of the five pillars of Islam and is a form of ibadah that should be performed by every individual Muslim. However, zakat collection in Malaysia is still low including income zakat. While most of employees pay income tax which is a legal obligation, they do not comply with zakat payment which is a religious obligation (Kamil, 2002); Zainol, Kamil, \& Faridahwati, (2009)). According to Raedah, Noormala, \& Marziana (2011), totals collection of zakat funds are still far behind as 
INTERNATIONAL JOURNAL OF ACADEMIC RESEARCH IN BUSINESS AND SOCIAL SCIENCES Vol. 8, No. 10, Oct. 2018, E-ISSN: 2222-6990 @ 2018 HRMARS

compared to collection of tax by the Inland Revenue Department. The highest contribution of zakat collection in Malaysia is mainly from zakat on employment income.

There are limited literatures on compliance behavior of zakat. Among them are Kamil (1995), Kamil (2002), Zainol (2008), Zainol et al., (2009), Ram Al Jaffri (2010), Nur Barizah \& Hafiz Majdi (2010), Mohd Rahim, Ariffin, \& Abd Samad (2011), Raedah et al. (2011), Halizah, Kasumalinda, \& Agoos Munalis (2011), Kamil, Zainol, \& Ram Al Jaffri (2012), Farah, Haji-Othman, \& Omar (2017), HajiOthman, Sheh Yusuff, Mohd Saufi, \& Al-Basri (2017), Haji-Othman \& Fisol (2017) and Haji-Othman (2016).

Zainol, Kamil and Faridahwati (2009) examined whether subjective norms and attitudes towards zakat are directly related to intention to comply with zakat on employment income in Malaysia, and also examined whether attitudes towards zakat mediate the relationship between subjective norms and intention using AMOS IV statistical program that involves structural equation modeling (SEM). The study found that subjective norms and attitudes had positive and significant influence on behavioral intention.

Zainol (2008) and Ram Al Jaffri (2010) examine the influence of religious teachers on intention to pay zakat. Zainol (2008) finds that there is no empirical support; however, Ram Al Jaffri (2010) found that the influence of religious teachers play an important role in the intention to pay zakat. In addition, Zainol (2008) and Ram Al Jaffri (2010) also examine the influence of parents on intention to pay zakat. The studies find that the influence of parents, which is categorized as intimate group, has an influence on the intention to pay zakat.

Furthermore, Zainol (2008) and Ram Al Jaffri (2010) examine the influence of peers on intention to pay zakat. Ram Al Jaffri (2010) provides empirical evidence showing the influence of peers on the intention to pay zakat. Zainol (2008), on the other hand, does not provide empirical evidence showing the influence of peers on the intention to pay zakat. Mohd Rahim, Ariffin and Abd Samad (2011) found that there were seven factors that influenced individuals to comply with zakat which are gender, age, educational stage, high expenses, and level of awareness about zakat scheme, matter of taxations, environmental concern and religiosity of individuals. Moreover, Raedah, Noormala and Marziana (2011) studied factors that influence academics' intention to pay zakat using a total of 600 questionnaires which were distributed to all academics in Kuantan, Pahang. They found that only attitude and perceived behavior control show significant relationship with intention to pay zakat.

The modern empirical studies show that the religiosity has an important impact on the lives of the zakat payers as well as its recipients (Hairunnizam 2012). Kamil et al. (2012) construct Islamic religiosity measurement and found that it has four dimensions and play an important role in influencing business income zakat. Kamil, Zainol and Ram (2012) constructed quantitative Islamic religiosity measurement from Islamic perspective and examined whether the Islamic religiosity measurement plays a significant role in compliance behavior of zakat. The study used questionnaires as instruments with a sample size of 227 . The study concluded that the components measurement of religiosity has four dimensions. Using regression analysis, this study found that business owners 
who are highly religious are also more likely to comply with zakat law and that religiosity plays an important role in zakat compliance behavior.

So far, there have been mixed and inconclusive empirical evidence regarding determinants of zakat compliance behavior. Therefore, there is still a gap of knowledge that needs to be explored further in order to have more understanding of determinants of zakat compliance behavior. It is very important to study compliance behavior of income zakat by public sector employees in Kedah in order to understand the determinants that contribute to their compliance behavior of zakat. By understanding the compliance behavior of income zakat payment, it could shed some lights on suitable policies to be formulated to increase income zakat collection. Income zakat collection would increase tremendously if the public servants are compliant to zakat payment.

The general objective of this study is to provide empirical evidence on the determinants of compliance behavior of income zakat. This research is a qualitative research; therefore it uses qualitative research methodology. According to Neuman (1997), a qualitative research is the systematic analysis of socially meaningful action through the direct detailed observation of people in natural settings in order to arrive at understandings and interpretations of how people create and maintain their social worlds.

\section{Research Design}

Research design for this study is interpretive design. Specifically, this study will use unstructured interview where we use tape recorder and note pad to tape and record the interviewee's responds. There are unstructured questions that the interviewer asks and the interviewees are allowed to answer freely. The interview then follows up certain points where necessary. The reason for using unstructured interview is to allow us to obtain much more detailed information than what is available through other data collection methods. It also enables us to ask some spontaneous questions which make the participants or interviewees to express themselves more freely.

Specifically, in order to understand the phenomena of zakat compliance, we will interview the respondents with unstructured questions to get in depth details of determinants of compliance and noncompliance of income zakat by public servants. The question that we usually ask is "what are your motivations for paying zakat". The interviewees are free to give responds and they are encouraged to give as many answers as possible. We then follow up their answers with spontaneous questions. The interviewees are free to express themselves. This enables the conversation to flow more freely which enables us to obtain as much information as possible.

The population of this study consists of UNISHAMS employees. Saturated approach is used to determine sample size. We ask respondents to explain motivation or factors that motivate them to comply with zakat payment. The data is collected until the answers are saturated. No new motivations are found by asking new respondents.

Data is obtained through direct interaction with respondents by unstructured interviews. 


\section{Research Analysis}

We use a thematic analysis. In order to analyze data obtained from the interviews, first we type all of the interviewees' responds in word document. Then, we read through the responds and search the common themes among the data. From the data, we find that there is variety of themes. Using NVIVO, the unstructured responds are coded in tree nodes.

We find that there is a variety of motivations for income zakat compliance. Among the common themes of motivations that are coded are:

i. Religious obligation

Refers to awareness of religious obligation to pay income zakat. Zakat is a compulsory Islamic religious duty upon all rich Muslims to be paid to the poor in the society, and its practice must be performed according to the prescribed methods by the Qur'an and

ii. Knowledge about Zakat

Sunnah.

Refers to one's knowledge about zakat. The knowledge could be obtained through formal or informal learning.

iii. Help the Poor

Refers to one's intention to help the poor and needy by paying zakat. It should be noted here that the primary objective of zakat is to eradicate poverty.

iv. Confidence in Fair Distribution of Zakat Collection to Asnaf

Refers to one's confidence in fair distribution of zakat by the Department of Zakat to asnaf.

v. Reward from Allah

Refers to one's intention to pay zakat is to get rewards from Allah in the hereafter.

vi. Help Muslim Community

vii. Influence of Parents

Refers to his/her hopes to help the Muslim community by paying zakat.

viii. Influence of Zakat Amil

Refers to his/her parents' influence to pay zakat.

ix. Tax Rebate Incentive

Refers to zakat amils' influence to pay zakat.

Refers to the tax rebate incentives given by the government for the zakat payers (Income

Tax Act 1967, 2006).

x. Purify One's Income and Property

Refers to his/her belief that paying zakat will purify income and property. Zakat purifies and cleanses wealth, and purifies the soul from stinginess and miserliness.

xi. Influence of Spouse

xii. Influence of Family

Refers to his/her spouse's influence to pay zakat.

xiii. Convenience to Pay Zakat

Refers to his/her families' influence to pay zakat.

Refers to convenience and facilities provided by the Department of Zakat to zakat payers to perform the duty of paying zakat. 
INTERNATIONAL JOURNAL OF ACADEMIC RESEARCH IN BUSINESS AND SOCIAL SCIENCES

Vol. 8, No. 10, Oct. 2018, E-ISSN: 2222-6990 (C) 2018 HRMARS

xiv. Influence of Religious Teacher

Refers to his/her religious teachers' influence to pay zakat.

\section{Research Findings}

This study finds that all of the respondents pay their income zakat. However, 8 of them make zakat payment to Kedah State Board of Zakat while 3 of them pay directly to the zakat asnafs. This finding shows that public servants pay zakat but not all of them pay zakat to the Kedah State Board of Zakat. This phenomenon causes the zakat collection by the Kedah State Board of Zakat to be lower than it should be. Based on the interview, we try to find common themes among the answers given by the interviewees. After we coded the themes using tree node in NVIVO, we came up with the following findings as reported in Table 1.

Table 1 Motivations for Paying Income Zakat by Respondents

\begin{tabular}{llc}
\hline & MOTIVATIONS FOR PAYING INCOME ZAKAT & FREQUENCY \\
\hline i) & Awareness about Zakat as a Religious Obligation & 9 \\
ii) & Knowledge about Zakat & 6 \\
iii) & To Help the Poor and Needy & 8 \\
iv) & Confidence in Fairness of Zakat Distribution & 3 \\
v) & To Obtain Reward from Allah in the Hereafter & 1 \\
vi) & To Help Improve Muslim Community & 1 \\
vii) & Influence of Parents & 2 \\
viii) & Influence of Zakat Amil & 2 \\
ix) & Tax Rebate & 2 \\
x) & To Purify Income and Property & 5 \\
xi) & Influence of Spouse & 1 \\
xii) & Influence of Family & 1 \\
xiii) & Convenience to Pay Zakat & 3 \\
xiv) & Influence of Religious Teachers & 1 \\
\hline
\end{tabular}

Table 1 shows that there 14 general themes of motivations for paying income zakat. Therefore, this study finds that there 14 motivations for employment income zakat among public servants in the state of Kedah. The motivations for paying employment income zakat in the state of Kedah are:

i) Awareness about Zakat as a Religious Obligation

ii) Knowledge about Zakat

iii) To Help the Poor and Needy

iv) Confidence in Fairness of Zakat Distribution

v) To Obtain Reward from Allah in the Hereafter

vi) To Help Improve Muslim Community

vii) Influence of Parents

viii) Influence of Zakat Amil

ix) Tax Rebate

x) To Purify Income and Property 
INTERNATIONAL JOURNAL OF ACADEMIC RESEARCH IN BUSINESS AND SOCIAL SCIENCES

Vol. 8, No. 10, Oct. 2018, E-ISSN: 2222-6990 @ 2018 HRMARS

xi) Influence of Spouse

xii) Influence of Family

xiii) Convenience to Pay Zakat

xiv) Influence of Religious Teachers

\section{Discussions}

This study finds that there are fourteen motivations or determinants of compliance behavior of income zakat by public servants in the State of Kedah. This study reveals that there 14 motivations for employment income zakat among public servants in the state of Kedah. The motivations for paying employment income zakat in the state of Kedah are:

i) Awareness about Zakat as a Religious Obligation

ii) Knowledge about Zakat

iii) To Help the Poor and Needy

iv) Confidence in Fairness of Zakat Distribution

v) To Obtain Reward from Allah in the Hereafter

vi) To Help Improve Muslim Community

vii) Influence of Parents

viii) Influence of Zakat Amil

ix) Tax Rebate

x) To Purify Income and Property

xi) Influence of Spouse

xii) Influence of Family

xiii) Convenience to Pay Zakat

xiv) Influence of Religious Teachers

We can further categorize them into 3 broad categories as shown by Figure 1 . 
Religious Obligation

To Help the Poor and Needy

To Purify Income

To Get Reward from Allah

To Help the Muslim Community

Influence of Spouse

Influence of Family

Influence of Parents

Influence of Religious Teachers

Influence of Zakat Amil

Facility/Convenience

Knowledge about Zakat

Confidence in Fairness and

Distribution

Tax Rebate

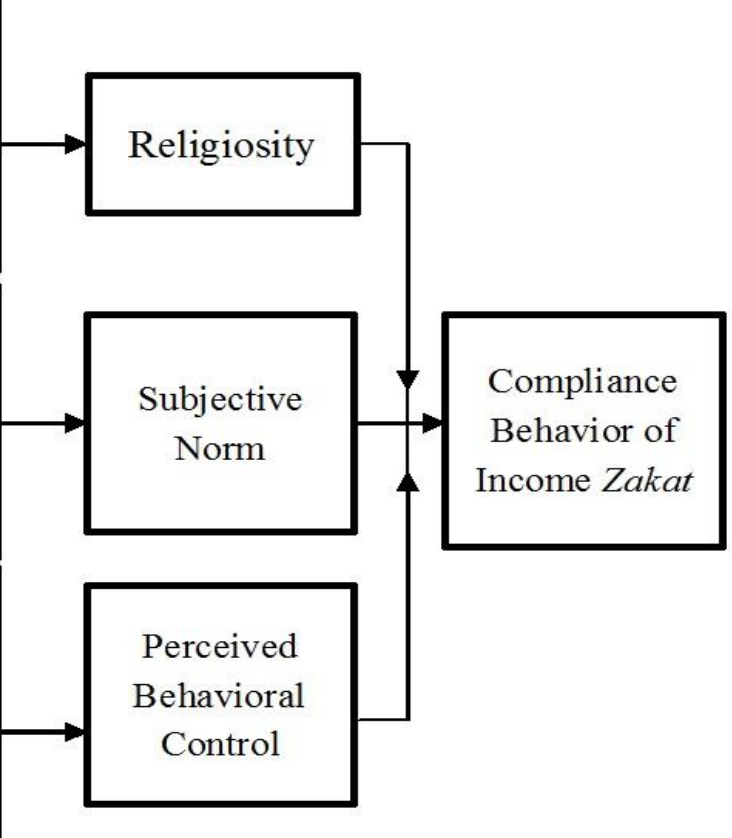

Figure 1: The Theory of Compliance Behavior of Income Zakat

The findings of this research are somewhat different form findings from previous research on compliance behavior of zakat. All previously reviewed literature shows that the research on compliance behavior of zakat use quantitative research. Most of them use the Theory of Planned Behavior (TPB) as the underpinning theory. Using the TPB, they formulate hypothesis, collect data and accept or reject the hypothesis. This is called deductive reasoning.

However, this research employs a qualitative research approach. Instead of using deductive reasoning, we employ inductive reasoning. We observe the phenomena using interviews, analyze themes, formulate relationships and come up with a theory as shown in Figure 1. This finding is important for several reasons. This study provides empirical evidence that the three significant motivations of compliance behavior are religiosity, subjective norms and perceived behavioral control. The interesting fact is that this finding has some similarity to the Theory of Planned Behavior proposed by Ajzen (1991) in a sense that there are two similar independent variables in the two studies: subjective norms and perceived behavioral control.

However, the finding of this study differs from those of Ajzen (1991) in two different aspects. The first is that while this study reveals that the most important determinant of compliant behavior is religiosity, Ajzen (1991) proposed attitude as the first determinant of intention. Religiosity is found to be the most significant determinants of religiosity because this study examines compliance behavior of income zakat which is a religious obligation, therefore, it is not surprising that religiosity is the most significant determinant. On the other hand, according to Ajzen (1991), attitude can influence a person's intention by increasing the person's motivation to engage in a particular behavior. Individuals are more likely to engage in behaviors that are perceived to have favorable 
INTERNATIONAL JOURNAL OF ACADEMIC RESEARCH IN BUSINESS AND SOCIAL SCIENCES

Vol. 8, No. 10, Oct. 2018, E-ISSN: 2222-6990 @ 2018 HRMARS

outcomes for them and are less likely to engage in activities that are associated with unfavorable outcomes. The second difference is that, unlike Ajzen (1991), this study does not treat intention as a mediating variable because in Islamic deeds, intention is part of compliance.

\section{Conclusion and Recommendations}

This study attempts to examine motivations of paying income zakat by using interview method and comes up with a different framework than the previous frameworks used to examine this area of futile research such as the Theory of Planned Behavior. Unlike the Theory of Planned Behavior which proposed attitude, subjective norms and perceived behavioral control as the independent variables which influence intention, which in turn influences compliance behavior, this study proposes that religiosity, subjective norms and perceived behavioral control influences compliance behavior,

It is very important to understand zakat payers' motivations. As we understand their motivations, we can take the necessary steps to increase zakat collection. When zakat collection is increased, zakat can play a more important role as a significant tool of Islamic finance. Although there are voluminous literatures on the compliance behavior of zakat, almost all of them use quantitative approach. The findings of this research are different from previous research findings because of the different approach.

This study recommends that more comprehensive studies to be done in the area of zakat compliance behavior using qualitative approach and future studies should attempt to use the framework proposed by this study as their underpinning theory. In addition, this study proposes that future studies regarding compliance behavior of religious obligations such as compliance behavior of zakat, Islamic banking, takaful, faraid, waqaf and others adapt and adopt the theory proposed by this study. It is hoped that compliance behavior of religious obligations would be a fertile area of research in the future.

\section{References}

Abu Bakar, N. B., \& Rashid, H. M. A. (2010). Motivations of Paying Zakat on Income: Evidence from Malaysia. International Journal of Economics and Finance, 2(3). http://doi.org/10.5539/ijef.v2n3p76

Ajzen, I. (1991). The theory of planned behavior. Organizational Behavior and Human Decision Processes, 50(2), 179-211. http://doi.org/10.1016/0749-5978(91)90020-T

Farah, J. M. S., Haji-Othman, Y., \& Omar, M. M. (2017). The Influence of Attitude, Religiosity, and Perception towards Law Enforcement on Intention towards Compliance Behaviour of Income Zakat among KUIN Staff in Kedah, Malaysia. International Journal of Muamalat, 1(1), 25-45.

Haji-Othman, Y. (2016). Motivations for Paying Income Zakat among Public School Teachers in Kedah, Malaysia : A Qualitative Approach. International Journal of Novel Research in Humanity and Social Sciences, 3(6), 37-42.

Haji-Othman, Y., \& Fisol, W. N. M. (2017). Islamic Religiosity, Attitude and Moral Obligation on Intention of Income Zakat Compliance: Evidence from Public Educators in Kedah. Journal of Academic Research in Business ..., 7(2), 726-737. http://doi.org/10.6007/IJARBSS/v7-i2/2680 
INTERNATIONAL JOURNAL OF ACADEMIC RESEARCH IN BUSINESS AND SOCIAL SCIENCES

Haji-Othman, Y., Sheh Yusuff, M. S., Mohd Saufi, M. S. A., \& Al-Basri, S. H. (2017). The Influence of Knowledge, Islamic Religiosity and Self- Efficacy on the Intention to Pay Income Zakat among Public Educators in Kedah, Malaysia. International Journal of Academic Research in Business and Social Sciences, 7(11), 1117-1127. http://doi.org/10.6007/IJARBSS/v7-i11/3550

Halizah, M. A., Kasumalinda, A., \& Agoos Munalis, T. (2011). Factors Influence Company Towards Zakat Payment: An Explanatory Studies.

Kamil, M. I. (1995). Kesan Persepsi Undang-Undang dan Penguatkuasaan Zakat Terhadap Gelagat Kepatuhan Zakat Pendapatan Gaji.

Kamil, M. I. (2002). Gelagat Kepatuhan Zakat Pendapatan Gaji di Kalangan Kakitangan Awam Persekutuan Negeri Kedah.

Kamil, M. I., Zainol, B., \& Ram Al Jaffri, S. (2012). Islamic Religiosity Measurement and Its Relationship with Business Income Zakat Compliance Behavior. Jurnal Pengurusan, 34, 3-10.

Mohd Rahim, K., Ariffin, M. S., \& Abd Samad, N. (2011). Compliance Behavior of Business Zakat Payment in Malaysia : A Theoretical Economic Exposition.

Raedah, S., Noormala, A., \& Marziana, M. (2011). A Study on Zakah of Employment Income: Factors that Influence Academics' Intention to Pay Zakah.

Ram Al Jaffri, S. (2010). Gelagat Kepatuhan Zakat Perniagaan di Negeri Kedah Darul Aman.

Zainol, B. (2008). Faktor-faktor Penentu Niat Gelagat Kepatuhan Zakat Pendapatan Gaji.

Zainol, B., Kamil, M. I., \& Faridahwati, M. S. (2009). Predicting Compliance Intention on Zakah on Employment Income in Malaysia : An Application of Reasoned Action Theory. Jurnal Pengurusan, 28, 85-102. 